\title{
AN ANALYSIS OF REGIONAL ECONOMIC GROWTH AND CAPITAL EXPENDITURE ON SELF-GENERATED REVENUE IN SUPIORI REGENCY
}

\author{
Ketrina Arwakom ${ }^{10}$ \\ arwakomketrina@gmail.com \\ Syaikhul Falah ${ }^{11}$ \\ sehufalah@gmail.com \\ Anthonius H Citra Wijaya ${ }^{12}$ \\ Anthoniuscitra@gmail.com
}

\begin{abstract}
The purpose of this research is to evaluate the effect of the economic growth and the capital expenditures on self-generated revenue of Supiori Regency during 2008 to 2014 partially and simultaneously. This research was a causative research aims to test hypotheses and explain the phenomenon in relation of the research variables. Data collected was from secondary sources such as government publication documents comprise of economic growth information, the amount of capital expenditures, and the region self-generated revenue. The population in this study was Audited Budget Realisation Report and economic growth of Supiori Regency and Papua Province from 2008 to 2014. While the sample consisted of economic growth information based on accepted prices, capital expenditures and self-generated revenue of Supiori Regency and Papua province from 2008 to 2014. All these data being analyzed used a classical assumption test and path analysis.

According to the analysis, the results showed that the economic growth of Supiori Regency has a positive and signicant effect on self-generated revenue of Supiori partialy and simultaneously in 2008 to 2014. While the allocation for capital expenditures from 2008 to 2014 has positive effect but not significant on the regional self-generated revenue in Supiori partially and simultaneously. Also, the allocation of capital expenditure and the economic development from 2008 to 2014 have positive but not significant effect on the regional self-generated revenue in Supiori partially and simultaneously. As can be seen from the pattern of correlation from each variables, this study conluded that the capital expenditures was not the intervening variables to the progress of the region selfgenerated revenue in Supiori Regency.
\end{abstract}

Keywords : Self-Generated Revenue, Economic Growth, Capital Expenditure

\section{PENDAHULUAN}

Hasil Laporan Analisis Penerimaan dan Pengeluaran Publik Kabupaten Supiori (2013), menunjukkan bahwa pengelolaan keuangan

\footnotetext{
${ }^{10}$ Alumni Mahasiswa Magister Keuangan Daerah Universitas Cenderawasih

${ }^{11,12}$ Staf Dosen Jurusan Akuntansi Fakultas Ekonomi dan Bisnis Universitas Cenderawasih
} 
daerah di Kabupaten Supiori secara umum dinilai masih kurang baik sehingga perlu pembenahan disemua bidang. Kerangka peraturan perundangan daerah memperoleh skor 14,29 persen (sangat kurang); Perencanaan dan penganggaran 31,5 persen (sangat kurang); Pengelolaan kas 53,3 persen (cukup); Pengadaan Barang dan jasa 45 persen (kurang); Akuntansi dan pelaporan 45 persen (kurang); Pengawasan internal 38,8 persen (sangat kurang); Hutang dan investasi publik 40 persen (kurang); Pengelolaan aset 20 persen (sangat kurang); dan audit dan pengawasan eksternal 30 persen (sangat kurang). Berdasarkan skor capaian di atas, maka kesembilan bidang tersebut perlu dilakukan perbaikan untuk terwujudnya efisiensi, efektivitas, transparansi, dan akuntabilitas pengelolaan keuangan daerah ke arah yang lebih baik.

Tingkat ketergantungan pemerintah Kabupaten Supiori terhadap pendanaan dari pusat masih cukup besar. Rata-rata proporsi PAD Kabupaten Supiori selama sepanjang tahun 2007-2011 masih relative kecil yaitu hanya sebesar 1,31 persen. Secara umum, pendapatan daerah masih didominasi oleh pendapatan transfer dari pusat yang mencapai rata-rata 80 persen. Dana transfer tersebut didominasi oleh dana perimbangan dimana DAU masih merupakan sumber utama. Sedangkan, dana Otonomi Khusus yang merupakan bagian dari Penerimaan dari Provinsi Papua dan diklasifikasikan sebagai pendapatan lain yang sah mencapai rata-rata sebesar 15 persen. Sumber PAD terbesar berasal dari Lain -Lain PAD yang sah, meskipun cenderung mengalami penurunan dalam periode 2007-2011. Penerimaan PAD yang sah pada tahun 2007 cukup besar, akan tetapi tahun berikutnya menurun hingga tahun 2010. Pada tahun 2011, Lain PAD yang sah meningkat tetapi tidak sebesar dengan nilai tahun 2007. Sumber PAD terbesar kedua yaitu Hasil Pengelolaan Kekayaan Dipisahkan. Peranan pajak dan retribusi masih menempati porsi terkecil dari pembentukkan PAD. Kondisi ini mengindikasikan belum 
optimalnya potensi pendapatan yang bersumber dari pelayanan kepada masyarakat. Proporsi belanja terbesar berdasarkan klasifikasi ekonomi didominasi oleh belanja modal. Meskipun kecenderungan menurun proporsi belanja modal dari 60,61 persen pada tahun 2007 menjadi 43,79 persen pada tahun 2011, namun secara rata-rata proporsinya sebesar 47,76 persen lebih besar dari proporsi belanja barang dan jasa (27 persen) serta belanja pegawai (21 persen). Proporsi belanja modal terhadap belanja langsung mendekati 60 persen. (Hasil Laporan Analisis Penerimaan dan Pengeluaran Publik Kabupaten Supiori, 2013).

Tingginya proporsi belanja modal menjelaskan tingginya perhatian pemerintah menambah nilai investasi untuk mendorong pertumbuhan ekonomi dan pelayanan publik baik di masa kini maupun masa yang akan datang. Proporsi belanja lain-lain meskipun kecil, namun beberapa komponen belanja didalamnya mengalami peningkatan di tahun 2011 seperti belanja bantuan sosial dan belanja ke daerah bawahan. Pemerintah Kabupaten Supiori mengalokasikan belanja di sektor kesehatan sebagian besar untuk belanja barang dan jasa dan belanja modal. Sedangkan proporsi belanja daerah sektor pendidikan sebagian besar dialokasikan pada belanja modal. Kondisi ini menjelaskan bahwa perhatian pemerintah daerah terhadap investasi prasarana dan sarana kesehatan dan pendidikan yang semakin membaik.

Dalam aplikasi pembangunan di Kabupaten Supiori, diharapkan dapat meningkatkan pertumbuhan ekonomi dengan mengoptimalkan belanja modal yang lebih tepat sasaran dan efektif. Peningkatan pertumbuhan ekonomi dan pengoptimalan belanja modal diharapkan dapat meningkatkan PAD. Peningkatan pertumbuhan ekonomi suatu daerah juga mampu menarik minat investor untuk berinvestasi di daerah sehingga sumber-sumber PAD terutama yang berasal dari pajak daerah akan semakin meningkat. Hal ini akan meningkatkan 
sumber penerimaan daerah dan tentu saja akan membuat penerimaan PAD semakin tinggi. Sedangkan di lain pihak peningkatan belanja modal yang dialokasikan oleh pemerintah Kabuaten Supiori dalam pembangunan infrastruktur yang mampu memberikan dorongan pada gairah pembangunan dan minat investor dalam berusaha. Besarnya kewenangan yang diberikan kepada pemerintah daerah diharapkan mendorong Pemerintah Daerah Kabupaten Supiori untuk melaksanakan fungsinya secara efektif dalam pengambilan keputusan pelaksanaan pembangunan, dengan terus mengoptimalkan potensi dan sumber daya yang tersedia dengan lebih efektif dan terarah. Adapun tujuan penulisan ini adalah: 1) Untuk menguji pengaruh Pertumbuhan Ekonomi terhadap Pendapatan Asli Daerah (PAD) di Kabupaten Supiori. 2) Untuk melihat pengaruh Belanja Modal terhadap Pendapatan Asli Daerah (PAD) di Kabupaten Supiori. 3.)Untuk menguji pengaruh Belanja Modal terhadap Pertumbuhan Ekonomi di Kabupaten Supiori.

\section{METODE PENELITIAN}

\section{Jenis dan Sumber Data}

Dalam penelitian ini, data yang digunakan hanya berupa data sekunder. Adapun data-data sekunder dalam penelitian ini adalah:

a) LRA Kabupaten Supiori Tahun 2008-2014

b) Data Dalam Angka Kabupaten Supiori Tahun 2008-2014

\section{Metode Pengumpulan Data}

Dalam penelitian ini metode pengumpulan data yang digunakan adalah studi pustaka, dimana untuk mengumpulkan data sekunder tentang Keuangan Daerah dan Kondisi Makro ekonomi Kabupaten Supiori dilakukan pada instansi/lembaga yang telah diakui keberadaannya oleh Negara. Adapun jenis dan sumber data yang akan dikumpulkan adalah sebagai berikut: 
Tabel 1

Metode Pengumpulan Data

\begin{tabular}{|c|c|c|}
\hline No. & Jenis Data & Sumber \\
\hline 1. & $\begin{array}{c}\text { LRA Kabupaten Supiori } \\
\text { Tahun 2008-2014 }\end{array}$ & $\begin{array}{c}\text { Dinas Pengelolaan Keuangan } \\
\text { Dan Aset Daerah Kabupaten } \\
\text { Supiori }\end{array}$ \\
\hline 2. & $\begin{array}{c}\text { Data Dalam Angka Kabupaten } \\
\text { Supiori Tahun 2008-2014 }\end{array}$ & $\begin{array}{c}\text { Basan Pusat Statistik Kabupaten } \\
\text { Supiori dan Badan Perencanaan } \\
\text { Pembangunan Daerah }\end{array}$ \\
\hline
\end{tabular}

\section{Metode Analisis Data}

\section{Pengujian Asumi Klasik}

Sebelum dilakukan pengujian hipotesis dengan menggunakan Analisis Jalur,maka diperlukan pengujian asumsi klasik yang meliputi pengujian normalitas, mulikolinearitas, autokorelasi dan heteroskedastisitas.

\section{a. Uji Normalitas}

Uji normalitas data yang digunakan dalam penelitian ini adalah Uji Kolmogorov-Smirnov. Kriteria pengujian satu sampel menggunakan pungujian satu sisi yaitu dengan membandingkan probabilitas dengan tingkat signifikansi tertentu yaitu:

1) Nilai Signifikan atau probabilitas $<0,05$, maka distribusi data adalah tidak normal.

2) Nilai Signifikan atau probabilitas $>0,05$, maka distribusi data adalah normal. Selain melihat nilai signifikansi dari uji KolmogorovSmirnof, untuk melihat apakah suatu data mempunyai distribusi normal dapat dilihat dari melihat grafik.

\section{b. Uji Autokorelasi}

Ada beberapa cara yang dapat digunakan untuk mendeteksi ada tidaknya autokorelasi. Pertama, Uji Durbin-Watson (DW Test). Uji ini hanya digunakan untuk autokorelasi tingkat satu (first order 
autocorrelation) dan mensyaratkan adanya intercept dalam model regresi dan tidak ada variabel lag di antara variabel penjelas. Hipotesis yang diuji adalah:

Ho: $p=0$ (baca: hipotesis nolnya adalah tidak ada autokorelasi)

$\mathrm{H} 1: \mathrm{p} \neq 0$ (baca: hipotesis alternatifnya adalah ada autokorelasi)

Keputusan ada tidaknya autokorelasi adalah:

1) Bila nilai DW berada di antara $d_{U}$ sampai dengan 4- $d^{U}$ maka koefisien autokorelasi sama dengan nol. Artinya, tidak ada autokorelasi.

2) Bila nilai DW lebih kecil daripada $d_{L}$, koefisien autokorelasi lebih besar daripada nol. Artinya ada autokorelasi positif.

3) Bila nilai DW terletak di antara $d_{L}$ dan $d_{U}$ maka tidak dapat disimpulkan.

4) Bila nilai DW lebih besar daripada 4- $d_{L}$, koefisien autokorelasi lebih besar daripada nol. Artinya ada autokorelasi negatif.

5) Bila nilai DW terletak di antara 4- $d U$ dan 4-dL, maka tidak dapat disimpulkan.

\section{c. Uji Multikolinearitas}

Uji multikolinearitas bertujuan untuk menguji, apakah ditemukan atau tidak korelasi diantara variabel independen. Jika terjadi korelasi antar variabel independen maka akan ditemukan adanya masalah multikolinearitas. Suatu model regresi yang baik harus tidak menimbulkan masalah multikolinearitas. Untuk itu diperlukan uji multikolinearitas terhadap setiap data variabel bebas yaitu dengan:

1) Melihat angka collinearity Statistics yang ditunjukkan oleh Nilai Variance Inflation Factor (VIF). Jika angka VIF lebih besar dari 10, maka variabel bebas yang ada memiliki masalah multikolinearitas.

2) Melihat nilai tolerance pada output penilaian multikolinearitas yang tidak menunjukkan nilai yang lebih besar dari 0,1 akan memberikan kenyataan bahwa tidak terjadi masalah multikolinearitas (Ghozali, 2001). 


\section{d. Uji Heterokedastisitas}

Heterokedastisitas terjadi dalam regresi apabila varian error (ei) untuk beberapa nilai $x$ tidak konstan atau berubah-ubah. Pendeteksian konstan atau tidaknya varian error konstan dapat dilakukan dengan menggambar grafik antara $y$ dengan residu $(y-y)$. Apabila garis yang membatasi sebaran titik -titik relatif paralel maka varian error dikatakan konstan.

\section{Analisis Jalur (Path Analysis)}

Teknik analisis yang dipergunakan untuk menjawab masalah adalah analisis jalur (Path Analysis) dengan menggunakan software SPSS (Statistical Package for Sosial Sciense). Terdapat suatu variabel dalam analisis jalur yang berperan ganda yaitu sebagai variabel independent pada suatu hubungan, namun menjadi variable dependent pada hubungan lain mengingat adanya hubungan kausalitas yang berjenjang. Penyusunan langkah-langkah dalam Analisis Jalur (Path Analysis) sebagai berikut (Solimun, 2002): pertama, merancang model berdasarkan konsep dan teori, berdasarkan hubungan antar variabel dapat dibuatmodel dalam diagram path sebagai berikut: Model dalam Gambar 3.1 dapat dinyatakan dalam bentuk persamaan sehingga membentuk system persamaan yang dinamakan sistem persamaan simultan atau model struktural. Hubungan kausal antara variabel $\mathrm{X} 1, \mathrm{X} 2, \mathrm{X} 3$, dan $\mathrm{Y}$. Kedua, pemeriksaan terhadap asumsi yang melandasi. Asumsi yang melandasianalisis Path adalah (a) di dalam model analisis path, hubungan antar variabel adalah linear aditif dan bersifat normal; (b) hanya model rekursif dapat dipertimbangkan yaitu hanya sistem aliran kausal ke satu arah. Model tidak mengandung kausal resiprokal atau arah kausalitas yang berbalik; (c) variabel terikat (endogen) minimal skala ukur interval dan ratio; (d) observed variabelsdiukur tanpa kesalahan (instrumen 
pengukuran valid dan reliable); (e) model yang dianalisis dispesialisasikan (identifikasi) dengan benar berdasarkan teori-teori dan konsep-konsep yang relevan. Ketiga, pendugaan parameter (perhitungan koefesien path). Sesuai dengan hipotesis dan kerangka pikir yang dibangun, maka model analisis jalur yang petama dalam penelitian ini dapat dirumuskan sebagai berikut (Naz'aina, 2013):

$Y=a+b 1 X 1+e$

Di mana:

a : Nilai intersep (konstan)

b : : Slope atau Koefisien Regresi

Y : Pendapatan Asli Daerah

X1 : Pertumbuhan Ekonomi

e : Error

Sedangkan dengan hipotesis dan kerangka pikir yang ada, maka model analisis jalur yang kedua dalam penelitian ini dapat dirumuskan sebagai berikut (Naz'aina, 2013):

$\mathrm{Y}=\mathrm{a}+\mathrm{b} 2 \mathrm{X} 2+\mathrm{e}$

Di mana:

$\begin{array}{ll}\text { a } & \text { : Nilai intersep (konstan) } \\ \text { b } & \text { : Slope atau Koefisien Regresi } \\ \text { Y } & \text { : Pendapatan Asli Daerah } \\ \mathrm{X} 2 & \text { : Belanja Modal } \\ \mathrm{e} & \text { : Error }\end{array}$

Sedangkan dengan hipotesis dan kerangka pikir yang ada, maka model analisis jalur yang ketiga dalam penelitian ini dapat dirumuskan sebagai berikut (Naz'aina, 2013):

$X 1=a+b 3 X 2+e$

Di mana:

a : Nilai intersep (konstan)

b : : Slope atau Koefisien Regresi

X1 : Pertumbuhan Ekonomi

X2 : Belanja Modal

e : Error 
Berdasarkan hipotesis dan kerangka pikir yang dibangun, maka model analisis jalur yang keempat dalam penelitian ini dapat dirumuskan sebagai berikut (Naz'aina, 2013):

$$
\mathrm{Y}=\mathrm{a}+\mathrm{b} 2 \mathrm{X} 2+\mathrm{b} 1 \mathrm{X} 1+\mathrm{e}
$$

Di mana:

$$
\begin{array}{ll}
\text { a } & \text { : Nilai intersep (konstan) } \\
\text { b } & \text { : Slope atau Koefisien Regresi } \\
\text { Y } & \text { : Pendapatan Asli Daerah } \\
\text { X2 } & \text { : Belanja Modal } \\
\text { X1 } & \text { : Pertumbuhan Ekonomi } \\
\text { e } & \text { : Error }
\end{array}
$$

Seluruh persamaan jalur di atas dapat digambarkan sebagai berikut:

\section{Gambar 1. Diagram Analisa Jalur}

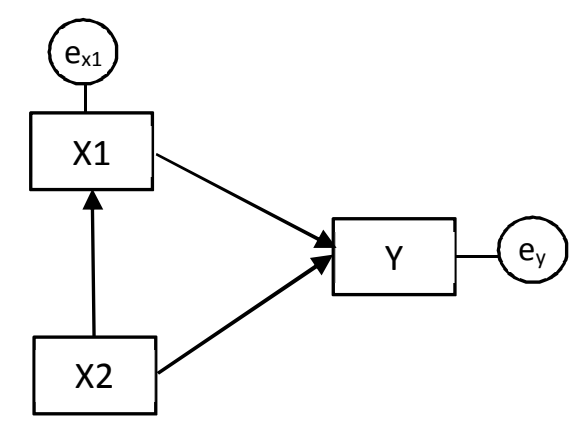

\section{Pengujian Hipotesis}

Pengujian hipotesis dilakukan untuk memperoleh kebenaran atas apa yang telah di hipotesiskan pada bab tinjauan pustaka. Hipotesis merupakan jawaban sementara terhadap masalah yang diteliti, dimana jawaban itu masih bersifat lemah, dan perlu dilakukan pengujian secara empiris kebenarannya, dengan melakukan pembuktian statistik. Dalam penelitian ini hanya menggunakan Uji t. Dimana Uji t digunakan untuk menguji signifikasi hubungan antara variabel $X$ dan $Y$, apakah variabel $\mathrm{X} 1$ dan $\mathrm{X} 2$ (pertumbuhan ekonomi dan belanja modal) benar-benar berpengaruh terhadap variabel $Y$ (pendapatan asli daerah) secara individual atau parsial (Ghozali, 2006). 
Hipotesis yang digunakan dalam pengujian ini adalah:

HO : Secara parsial tidak ada pengaruh signifikan antara variablevariabel bebas terhadap variabel terikat

$\mathrm{H} 1$ : Secara parsial terdapat pengaruh signifikan antara variablevariabel bebas terhadap variabel terikat

Untuk menguji signifikan atau tidaknya koefisien jalur secara parsial, dapat digunakan uji t dengan rumus:

$$
t=\frac{r \sqrt{n-2}}{r \sqrt{1-r^{2}}}
$$

Dimana:

$r \quad=$ Nilai koefisien korelasi

$\mathrm{n} \quad=$ Jumlah populasi

r2 = Nilai koefisien determinasi atau kuadrat koefisien korelasi

(Sumber : Ghozali, 2003)

Hasil yang diperoleh dibandingkan dengan $t$ tabel. Bila nilai $t$ hitung $>t$ tabel, berarti pengaruh variabel $X$ terhadap $Y$ signifikan.

\section{HASIL ANALISIS DAN PEMBAHASAN}

\section{Deskriptif Penelitian}

\section{Deskriptif Sampel Penelitian}

Data yang dipergunakan pada penelitian ini adalah Laporan Anggaran Kabupaten Supiori yaitu laporan realisasi anggaran tahun 2008-2014 (7 tahun) sehingga jumlah sampel menjadi 69. Dari laporan tahunan tersebut yang menjadi objek penelitian adalah Realisasi Pendapatan Asli Daerah (PAD), Dana Alokasi Umum (DAU), Dana Alokasi Khusus (DAK), Belanja Modal dan Pertumbuhan Ekonomi yang diproyeksikan dengan PDRB harga berlaku tahun 2008-2014. Data diperoleh dari Badan Pusat Statistik Kabupaten Supiori dan Badan Perencanaan Pembangunan Daerah Kabupaten Supiori. 


\section{Statistik Deskriptif Data Penelitian}

Statistik deskriptif untuk setiap variabel bebas yang dianalisis disajikan pada Tabel 4.5 Variabel bebas yang digunakan dalam analisis ini sebanyak 2 (dua) variabel independen yaitu Pertumbuhan Ekonomi (X1), dan Belanja Modal (X2). Sedangkan variabel dependen yaitu Pendapatan Asli Daerah (Y). Hal tersebut terdapat pada Tabel berikut:

\section{Tabel 2}

\section{Statistik Deskriptif Descriptive Statistics}

\begin{tabular}{|l|c|r|r|r|r|}
\hline & N & \multicolumn{1}{|c|}{ Minimum } & \multicolumn{1}{c|}{ Maximum } & \multicolumn{1}{c|}{ Mean } & \multicolumn{1}{c|}{ Std. Deviation } \\
\hline BM & 7 & $83,812,215,151.00$ & $295,009,358,625.00$ & $187,572,421,599.71$ & $65,296,146,835.00$ \\
PE & 7 & $110,849,694,974.00$ & $152,031,270,490.71$ & $131,693,490,887.59$ & $14,653,149,712.61$ \\
PAD & 7 & $4,937,827,631.95$ & $10,186,662,337.51$ & $7,182,362,065.63$ & $2,041,183,470.64$ \\
Valid N & 7 & & & & \\
(listwise) & 7 & & & & \\
\hline
\end{tabular}

Sumber: data diolah, 2015

Dari Tabel statistik deskriptif diatas dapat dilihat bahwa Belanja Modal terendah yaitu sebesar Rp. 83,812,215,151,- dan yang tertinggi sebesar Rp 295,009,358,625,- dengan rata-rata Belanja Modal sebesar Rp 187,572,421,599,- setiap tahunnya. Pertumbuhan Ekonomi terendah di Kabupaten Supiori yaitu sebesar Rp 110,849,694,974,dan yang tertinggi sebesar Rp 152,031,270,490,- dengan rata-rata Pertumbuhan Ekonomi sebesar Rp 131,693,490,887,-- setiap tahunnya. Sedangkan Pendapatan Asli Daerah terendah di Kabupaten Supiori yaitu sebesar Rp 4,937,827,631,- dan yang tertinggi sebesar Rp 10,186,662,337,-dengan rata-rata Pertumbuhan Ekonomi sebesar Rp $7,182,362,065,-$ setiap tahunnya.

\section{Uji Asumsi Klasik}

\section{Uji Normalitas}

Uji normalitas data dimaksudkan untuk memperlihatkan bahwa data sampel berasal dari populasi yang berdistribusi normal. Ada 
beberapa teknik yang dapat digunakan untuk menguji normalitas data, antara lain uji chikuadrat, uji lilliefors, dan uji kolmogorov-smirnov.

Tabel 3

Uji Normalitas

Tests of Normality
\begin{tabular}{|l|r|r|r|r|r|r|}
\hline \multirow{5}{*}{} & \multicolumn{2}{|c|}{ Kolmogorov-Smirnov ${ }^{\mathrm{a}}$} & \multicolumn{3}{c|}{ Shapiro-Wilk } \\
\cline { 2 - 7 } & Statistic & df & \multicolumn{1}{c|}{ Sig. } & Statistic & df & \multicolumn{1}{c|}{ Sig. } \\
\hline PE & .109 & 7 & $.200^{*}$ & .982 & 7 & .970 \\
PAD & .246 & 7 & $.200^{*}$ & .859 & 7 & .148 \\
BM & .174 & 7 & $.200^{*}$ & .978 & 7 & .950 \\
\hline
\end{tabular}

*. This is a lower bound of the true significance.

a. Lilliefors Significance Correction

Sumber: data diolah, 2015

Keluaran pada gambar di atas menunjukkan uji normalitas data yang sudah diuji dengan uji Kolmogorov-Smirno v. Pengujian dengan SPSS berdasarkan pada uji Kolmogorov-Smirnov. Hipotesis yang diuji adalah:

$\mathrm{HO}$ : Sampel berasal dari populasi berdistribusi normal

H1 : Sampel tidak berasal dari populasi berdistribusi normal

Dengan demikian, normalitas dipenuhi jika hasil uji tidak signifikan untuk suatu taraf signifikasi (a) tertentu (Biasanya a $=0.05$ atau 0.01). Sebaliknya, jika hasil uji signifikan maka normalitas tidak terpenuhi. Cara mengetahui signifikan atau tidak signifikan hasil uji normalitas adalah dengan memperhatikan bilangan pada kolom signifikansi (Sig.). Untuk menetapkan kenormalan, kriteria yang berlaku adalah sebagai berikut:

a. Tetapkan tarap signifikansi uji misalnya $a=0.05$

b. Bandingkan $p$ dengan taraf signifikansi yang diperoleh

c. Jika signifikansi yang diperoleh $>$ a, maka sampel berasal dari populasi yang berdistribusi normal 
d. Jika signifikansi yang diperoleh < a, maka sampel bukan berasal dari populasi yang berdistribusi normal

Pada hasil di atas diperoleh taraf signifikansi dan untuk kelompok variabel adalah 0.20 . dengan demikian, data tidak berasal dari populasi yang berdistribusi normal, pada taraf signifikansi 0.05 .

\section{Uji Autokorelasi}

Ada beberapa cara yang dapat digunakan untuk mendeteksi ada tidaknya autokorelasi. Pertama, Uji Durbin-Watson (DW Test). Uji ini hanya digunakan untuk autokorelasi tingkat satu (first order autocorrelation) dan mensyaratkan adanya intercept dalam model regresi dan tidak ada variabel lagi di antara variabel penjelas.

\section{Tabel 4}

Uji Autokorelasi

Model Summary ${ }^{\text {b }}$

\begin{tabular}{|l|c|r|r|r|r|}
\hline Model & R & R Square & $\begin{array}{c}\text { Adjusted R } \\
\text { Square }\end{array}$ & $\begin{array}{c}\text { Std. Error of the } \\
\text { Estimate }\end{array}$ & $\begin{array}{c}\text { Durbin- } \\
\text { Watson }\end{array}$ \\
\hline 1 & $.836^{\mathrm{a}}$ & .699 & .549 & 1371325190.50396 & 2.501 \\
\hline
\end{tabular}

a. Predictors: (Constant), PE, BM

b. Dependent Variable: PAD

Sumber: data diolah, 2015

Langkah selanjutnya adalah menetapkan nilai $d_{\llcorner}$dan $d_{u}$. Caranya adalah dengan menggunakan derajat kepercayaan 5 persen, sampel (n) yang kita miliki sebanyak 7 observasi, dan variabel penjelas sebanyak 3 maka dapatkan nilai $d_{L}$ dan $d_{u}$ sebesar 2,678 dan 2,860. Maka dapat disimpulkan bahwa model ini memiliki gejala autokorelasi positif.

\section{Uji Multikolinieritas}

Suatu model regresi yang baik harus tidak menimbulkan masalah multikolinearitas. 


\section{Tabel 5 \\ Uji Multikolinieritas}

Coefficients $^{\mathrm{a}}$
\begin{tabular}{|ll|r|r|}
\hline \multicolumn{2}{|l|}{ Model } & \multicolumn{2}{|c|}{ Collinearity Statistics } \\
\cline { 3 - 4 } & & \multicolumn{1}{c|}{ Tolerance } & \multicolumn{1}{c|}{ VIF } \\
\hline \multirow{2}{*}{1} & $\mathrm{BM}$ & .514 & 1.946 \\
& $\mathrm{PE}$ & .514 & 1.946 \\
\hline
\end{tabular}
a. Dependent Variable: PAD
Sumber: data diolah, 2015

Dapat dilihat bahwa seluruh variabel penjelas memiliki nilai VIF lebih kecil dari 10 maka dapat disimpulkan bahwa model regresi ini tidak memiliki masalah Multikolinieritas.

\section{Uji Heterokedastisitas}

Tabel berikut menggambarkan hasil uji heterokedastisitas dengan grafik, untuk data hubungan antara Pertumbuhan Ekonomi (X1) dan Belanja Modal (X2) dengan Pendapatan Asli Daerah (Y), yang telah diuji linieritasnya.

\section{Gambar 1 \\ Uji Heterokedastisitas}

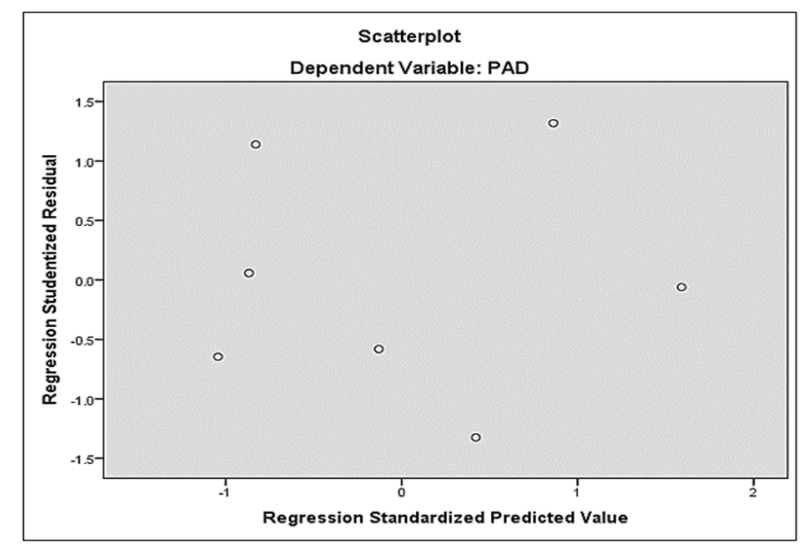

Sumber: data diolah, 2015

Pada grafik di atas tampak titik -titik menyebar di atas dan di bawah sumbu $\mathrm{Y}$, tidak terjadi pola tertentu. Dengan demikian dapat disimpulkan bahwa tidak terjadi heterokedastisitas. 


\section{PEMBAHASAN}

\section{Pengaruh Pertumbuhan Ekonomi Terhadap Pendapatan Asli Daerah (PAD)}

Uji $\mathrm{t}$ (parsial) adalah untuk melihat pengaruh variabel-variabel independen secara parsial terhadap variabel dependen. Dari hasil pengujian SPSS maka nilai uji t adalah sebagai berikut:

\begin{tabular}{|c|c|c|c|c|c|}
\hline Coefficients $^{\mathrm{a}}$ & & $\begin{array}{c}\text { Tabel } 6 \\
\text { Uji t }\end{array}$ & & & \\
\hline \multirow[t]{2}{*}{ Model } & \multicolumn{2}{|c|}{ Unstandardized Coefficients } & $\begin{array}{l}\text { Standardized } \\
\text { Coefficients }\end{array}$ & \multirow[t]{2}{*}{$\mathrm{t}$} & \multirow[t]{2}{*}{ Sig. } \\
\hline & B & Std. Error & Beta & & \\
\hline (Constant) & -7596379652.361 & 4886259894.646 & & -1.555 & .181 \\
\hline $\mathrm{PE}$ & .112 & .037 & .806 & 3.041 & .029 \\
\hline
\end{tabular}

a. Dependent Variable: PAD

Sumber: data diolah, 2015

Variabel pertumbuhan ekonomi (X1) memiliki koefisien jalur 0.806 artinya kecenderungan perubahan pertumbuhan ekonomi searah dengan perubahan pendapatan asli daerah. Berdasarkan angka koefisien jalur di atas dapat dinyatakan bahwa apabila pertumbuhan ekonomi ditingkatkan 1 kali, maka dapat meningkatkan pendapatan asli daerah Kabupaten Supiori sebesar 0.806 atau 80.6 persen. Jika nilai $t_{\text {hitung }}$ untuk variabel pertumbuhan ekonomi 3.041 dibandingkan nilai tabel 2.365 $(0,05: 7)$, maka nilai $t_{\text {hitung }}$ lebih besar dari $t_{\text {tabel }} \mathrm{Hal}$ ini berarti bahwa variabel pertumbuhan ekonomi terbukti mempengaruhi secara positif dan signifikan terhadap peningkatan pendapatan asli daerah, dengan probabilitas dan tingkat kesalahan pengukuran yang lebih kecil dari 5 persen $(P<0,05)$ yaitu 0,029 (3 persen). Sehingga hipotesis nol $(\mathrm{HO})$ ditolak dan hipotesis alternatif $(\mathrm{H} 1)$ diterima, dengan kata lain variabel independenX1 (pertumbuhan ekonomi) berpengaruh secara positif dan signifikan terhadap variabel dependen $Y$ (pendapatan asli daerah).

Berdasarkan hasil analisis jalur dengan menggunakan SPSS 18, maka diperoleh hasil Koefisien Determinasi $\left(R^{2}\right)$ sebagai berikut: 
Model Summary

\begin{tabular}{|l|r|r|r|c|}
\hline Model & \multicolumn{1}{|c|}{$\mathrm{R}$} & R Square & \multicolumn{1}{c|}{$\begin{array}{c}\text { Adjusted R } \\
\text { Square }\end{array}$} & $\begin{array}{c}\text { Std. Error of the } \\
\text { Estimate }\end{array}$ \\
\hline 1 & $.806^{\mathrm{a}}$ & .649 & .579 & 1324727938.47320 \\
\hline
\end{tabular}

a. Predictors: (Constant), PE

Sumber: data diolah, 2015

Berdasarkan hasil analisis jalur dengan menggunakan SPSS 18 pada tabel 4.10 di atas, diketahui bahwa variabel bebas berkorelasi yang positif dengan variabel terikat. Hal ini terlihat juga dari nilai koefisien Determinasi $\left(R^{2}\right)$ sebesar 0.649 atau 64.9 persen. Nilai Multiple $R^{2}$ sebesar 64.9 persen menunjukkan bahwa hubungan antara variabel bernilai positif yakni pertumbuhan ekonomi dengan variabel terikat pendapatan asli daerahtergolong kuat. Besarnya adjusted $\mathrm{R}^{2}$ adalah 64.9 persen, ini berarti 64.9 persen variasi pendapatan asli daerah bisa dijelaskan oleh variasi dari variabel independen (pertumbuhan ekonomi). Sedangkan sisanya (100 persen-64.9 persen $=33.1$ persen) dijelaskan oleh sebab-sebab yang lain diluar model.

\section{Pengaruh Belanja Modal Terhadap Pendapatan Asli Daerah (PAD) di Kabupaten Supiori}

Uji $\mathrm{t}$ (parsial) adalah untuk melihat pengaruh variabel-variabel independen secara parsial terhadap variabel dependen. Dari hasil pengujian SPSS maka nilai uji t adalah sebagai berikut:

\section{Tabel 8 \\ Uji t}

\begin{tabular}{|c|c|c|c|c|c|}
\hline \multicolumn{6}{|l|}{ Coefficients $^{\mathrm{a}}$} \\
\hline \multirow{2}{*}{ Model } & \multicolumn{2}{|c|}{ Unstandardized Coefficients } & $\begin{array}{l}\text { Standardized } \\
\text { Coefficients }\end{array}$ & \multirow[t]{2}{*}{$t$} & \multirow{2}{*}{ Sig. } \\
\hline & $\mathrm{B}$ & Std. Error & Beta & & \\
\hline (Constant) & 2947816276.450 & 1905727311.440 & & 1.547 & .183 \\
\hline BM & .023 & .010 & .722 & 2.335 & .067 \\
\hline
\end{tabular}

a. Dependent Variable: PAD

Sumber: data diolah, 2015 
Variabel belanja modal (X2) memiliki koefisien jalur 0.722 artinya kecenderungan perubahan belanja modal searah dengan perubahan pendapatan asli daerah. Berdasarkan angka koefisien jalur di atas dapat dinyatakan bahwa apabila belanja modal ditingkatkan 1 kali, maka dapat meningkatkan pendapatan asli daerah Kabupaten Supiori sebesar 0.722 atau 72.2 persen. Jika nilai $t_{\text {hitung }}$ untuk variabel belanja modal 2.335 dibandingkan nilai $t_{\text {tabel }} 2.365(0,05: 7)$, maka nilai $t_{\text {hitung }}$ lebih kecil dari tabel. Hal ini berarti bahwa variabel belanja modal tidak terbukti mempengaruhi secara positif dan signifikan terhadap peningkatan pendapatan asli daerah, dengan probabilitas dan tingkat kesalahan pengukuran yang lebih kecil dari 5 persen $(P<0,05)$ yaitu 0,069 ( 7 persen). Sehingga hipotesis nol $(\mathrm{HO})$ diterima dan hipotesis alternatif $(\mathrm{H} 1)$ ditolak, atau dengan kata lain variabel independen X2 (belanja modal) tidak berpengaruh secara positif dan signifikan terhadap variabel dependen $Y$ (pendapatan asli daerah).

Berdasarkan hasil analisis regresi dengan menggunakan SPSS 18, maka diperoleh hasil Koefisien Determinasi $\left(R^{2}\right)$ sebagai berikut:

Tabel 9

Uji $\mathbf{R}^{2}$

Model Summary
\begin{tabular}{|l|r|r|r|r|}
\hline Model & R & R Square & $\begin{array}{c}\text { Adjusted R } \\
\text { Square }\end{array}$ & $\begin{array}{c}\text { Std. Error of the } \\
\text { Estimate }\end{array}$ \\
\hline 1 & $.722^{\mathrm{a}}$ & .522 & .426 & 1546663997.91698 \\
\hline
\end{tabular}

a. Predictors: (Constant), BM

Sumber: data diolah, 2015

Berdasarkan hasil analisis jalur dengan menggunakan SPSS 18 pada tabel 4.12 di atas, diketahui bahwa variabel bebas berkorelasi yang positif dengan variabel terikat. Hal ini terlihat juga dari nilai koefisien Determinasi $\left(R^{2}\right)$ sebesar 0.522 atau 52.2 persen. Nilai Multiple $R^{2}$ sebesar 52.2 persenmenunjukkan bahwa hubungan antara variabel bernilai positif yakni belanja modal dengan variabel terikat pendapatan 
asli daerah tergolong cukup kuat. Besarnya adjusted $R^{2}$ adalah 52.2 persen, ini berarti 52.2 persen variasi pendapatan asli daerah bisa dijelaskan oleh variasi dari variabel independen (belanja modal). Sedangkan sisanya (100 persen- 52.2 persen $=47.7$ persen) dijelaskan oleh sebab-sebab yang lain diluar model.

\section{Pengaruh Belanja Modal Terhadap Pertumbuhan Ekonomi di Kabupaten Supiori}

Uji t (parsial) adalah untuk melihat pengaruh variabel-variabel independen secara parsial terhadap variabel dependen. Dari hasil pengujian SPSS maka nilai uji t adalah sebagai berikut:

Tabel 10

Uji t

\begin{tabular}{|c|c|c|c|c|c|}
\hline \multicolumn{6}{|l|}{ Coefficients $^{3}$} \\
\hline \multirow{2}{*}{ Model } & \multicolumn{2}{|c|}{ Unstandardized Coefficients } & \multirow{2}{*}{$\begin{array}{c}\begin{array}{c}\text { Standardized } \\
\text { Coefficients }\end{array} \\
\text { Beta }\end{array}$} & \multirow{2}{*}{$\mathrm{t}$} & \multirow{2}{*}{ Sig. } \\
\hline & B & Std. Error & & & \\
\hline \multirow[t]{2}{*}{ (Constant) } & 102342314121.457 & 14176797000.300 & & 7.219 & .001 \\
\hline & .156 & .072 & .697 & 2.175 & .082 \\
\hline
\end{tabular}

a. Dependent Variable: PE

Sumber: data diolah, 2015

Variabel belanja modal (X2) memiliki koefisien jalur 0.697 artinya kecenderungan perubahan belanja modal searah dengan perubahan pertumbuhan ekonomi. Berdasarkan angka koefisien jalur di atas dapat dinyatakan bahwa apabila belanja modal ditingkatkan 1 kali, maka dapat meningkatkan pertumbuhan ekonomi Kabupaten Supiori sebesar 0.697 atau 69.7 persen. Jika nilai thitung untuk variabel belanja modal 2.175 dibandingkan nilai tabel $2.365(0,05: 7)$, maka nilai $t_{\text {hitung }}$ lebih kecil dari $t_{\text {tabel. }}$. Hal ini berarti bahwa variabel belanja modal terbukti tidak mempengaruhi secara positif dan signifikan terhadap peningkatan pertumbuhan ekonomi, dengan probabilitas dan tingkat kesalahan pengukuran yang lebih kecil dari 5 persen $(P<0,05)$ yaitu 0,082 (8 persen). Sehingga hipotesis nol $(\mathrm{HO})$ diterima dan hipotesis 
alternatif $(\mathrm{H} 1)$ ditolak, dengan kata lain variabel independen $\mathrm{X} 2$ (belanja modal) tidak berpengaruh secara positif dan signifikan terhadap variabel dependen $Y$ (pertumbuhan ekonomi).

Berdasarkan hasil analisis jalur dengan menggunakan SPSS 18, maka diperoleh hasil Koefisien Determinasi $\left(R^{2}\right)$ sebagai berikut:

\section{Tabel 11}

Uji $\mathbf{R}^{2}$

Model Summary
\begin{tabular}{|l|r|r|r|r|}
\hline Model & R & R Square & $\begin{array}{c}\text { Adjusted R } \\
\text { Square }\end{array}$ & Std. Error of the Estimate \\
\hline 1 & $.697^{\mathrm{a}}$ & .486 & .383 & 11505707765.49243 \\
\hline
\end{tabular}

a. Predictors: (Constant), BM

Sumber: data diolah, 2015

Berdasarkan hasil analisis jalur dengan menggunakan SPSS 18 pada tabel 4.14 di atas, diketahui bahwa variabel bebas berkorelasi yang positif dengan variabel terikat. Hal ini terlihat juga dari nilai koefisien Determinasi $\left(R^{2}\right)$ sebesar 0.486 atau 48.6 persen. Nilai Multiple $\mathrm{R}^{2}$ sebesar 48.6 persen menunjukkan bahwa hubungan antara variabel bernilai positif yakni belanja modal dengan variabel terikat pertumbuhan ekonomi daerah tergolong cukup kuat. Besarnya adjusted $\mathrm{R}^{2}$ adalah 48.6 peraen, ini berarti 48.6 persen variasi pertumbuhan ekonomi daerah bisa dijelaskan oleh variasi dari variabel independen (belanja modal). Sedangkan sisanya (100 persen48.6 persen $=51.4$ persen) dijelaskan oleh sebab-sebab yang lain diluar model.

\section{Pengaruh Belanja Modal Terhadap Pendapatan Asli Daerah melalui Pertumbuhan Ekonomi di Kabupaten Supiori}

Uji t (parsial) adalah untuk melihat pengaruh variabel-variabel independen secara parsial terhadap variabel dependen. Dari hasil pengujian SPSS maka nilai uji t adalah sebagai berikut: 


\section{Tabel 12}

Uji t

Coefficients $^{3}$

\begin{tabular}{|l|r|r|r|r|r|}
\hline \multirow{2}{*}{ Model } & \multicolumn{2}{|c|}{ Unstandardized Coefficients } & \multicolumn{1}{c|}{$\begin{array}{c}\text { Standardized } \\
\text { Coefficients }\end{array}$} & \multirow{2}{*}{$\mathrm{t}$} & \multirow{2}{*}{ Sig. } \\
\cline { 2 - 5 } & \multicolumn{1}{|c|}{$\mathrm{B}$} & \multicolumn{1}{|c|}{ Std. Error } & \multicolumn{1}{c|}{ Beta } & & \\
\hline \multirow{2}{*}{ (Constant) } & -5432986011.585 & 5710727504.891 & & -.951 & .395 \\
1 BM & .010 & .012 & .312 & .816 & .460 \\
PE & .082 & .053 & .588 & 1.536 & .199 \\
\hline
\end{tabular}

a. Dependent Variable: PAD

Sumber: data diolah, 2015

Variabel belanja modal (X2) memiliki koefisien jalur 0.312 artinya kecenderungan perubahan belanja modal searah dengan perubahan pendapatan asli daerah. Berdasarkan angka koefisien jalur di atas dapat dinyatakan bahwa apabila belanja modal ditingkatkan 1 kali, maka dapat meningkatkan pendapatan asli daerah Kabupaten Supiori sebesar 0.312 atau 31.2 persen. Jika nilai thitung untuk variabel belanja modal 0.816 dibandingkan nilai tabel $2.365(0,05: 7)$, maka nilai $t_{\text {hitung }}$ lebih kecil dari $t_{\text {tabel. }}$. Hal ini berarti bahwa variabel belanja modal terbukti tidak mempengaruhi secara positif dan signifikan terhadap peningkatan pendapatan asli daerah, dengan probabilitas dan tingkat kesalahan pengukuran yang lebih kecil dari 5 persen $(P<0,05)$ yaitu $0,460$ (46 persen). Sehingga hipotesis nol ( $\mathrm{H} 0)$ diterima dan hipotesis alternatif $(\mathrm{H} 1)$ ditolak, dengan kata lain variabel independen X2 (belanja modal) tidak berpengaruh secara positif dan signifikan terhadap variabel dependen $\mathrm{Y}$ (pendapatan asli daerah).

Variabel pertumbuhan ekonomi (X1) memiliki koefisien jalur 0.588 artinya kecenderungan perubahan pertumbuhan ekonomi searah dengan perubahan pendapatan asli daerah. Berdasarkan angka koefisien jalur di atas dapat dinyatakan bahwa apabila belanja modal ditingkatkan 1 kali, maka dapat meningkatkan pendapatan asli daerah Kabupaten Supiori sebesar 0.588 atau 58.8 persen. Jika nilai thitung untuk variabel pertumbuhan ekonomi 1.536 dibandingkan nilai $t_{\text {tabel }} 2.365$ 
$(0,05: 7)$, maka nilai $t_{\text {hitung }}$ lebih kecil dari $t_{\text {tabel. }}$ Hal ini berarti bahwa variabel pertumbuhan ekonomi terbukti tidak mempengaruhi secara positif dan signifikan terhadap peningkatan pendapatan asli daerah, dengan probabilitas dan tingkat kesalahan pengukuran yang lebih kecil dari 5 persen $(P<0,05)$ yaitu 0,199 (19 persen). Sehingga hipotesis nol $(\mathrm{H} 0)$ diterima dan hipotesis alternatif $(\mathrm{H} 1)$ ditolak, dengan kata lain variabel independen $\mathrm{X} 1$ (pertumbuhan ekonomi) tidak berpengaruh secara positif dan signifikan terhadap variabel dependen $Y$ (pendapatan asli daerah).

Berdasarkan hasil analisis jalur dengan menggunakan SPSS 18, maka diperoleh hasil Koefisien Determinasi $\left(R^{2}\right)$ sebagai berikut:

\section{Tabel 13}

Uji $\mathbf{R}^{2}$

Model Summary
\begin{tabular}{|l|r|r|r|r|}
\hline Model & R & R Square & $\begin{array}{c}\text { Adjusted R } \\
\text { Square }\end{array}$ & $\begin{array}{c}\text { Std. Error of the } \\
\text { Estimate }\end{array}$ \\
\hline 1 & $.836^{\mathrm{a}}$ & .699 & .549 & 1371325190.50396 \\
\hline
\end{tabular}

a. Predictors: (Constant), PE, BM

Sumber: data diolah, 2015

Berdasarkan hasil analisis jalur dengan menggunakan SPSS 18 pada tabel 4.16 di atas, diketahui bahwa variabel bebas berkorelasi yang positif dengan variabel terikat. Hal ini terlihat juga dari nilai koefisien Determinasi $\left(R^{2}\right)$ sebesar 0,699 atau 69,9 persen. Nilai Multiple $R^{2}$ sebesar 69,9 persenmenunjukkan bahwa hubungan antara variabel bernilai positif yakni belanja modal dengan variabel terikat pertumbuhan ekonomi daerah tergolong cukup kuat. Besarnya adjusted $R^{2}$ adalah 69,9 persen, ini berarti 69,9 persen variasi pertumbuhan ekonomi daerah bisa dijelaskan oleh variasi dari variabel independen (belanja modal). Sedangkan sisanya (100 persen $-69,9$ persen $=30,1$ persen) dijelaskan oleh sebab-sebab yang lain diluar model. 


\section{Analisis Jalur (Path Analysis) dan Dekomposisi}

Analisis jalur (Path Analysis) dalam penelitian ini digambarkan melalui diagram jalur (path analysis) seperti terlihat pada gambar dibawah ini:

\section{Gambar 2}

Analisis Jalur Hubungan Variabel Pertumbuhan Ekonomi (X1), Belanja Modal (X2), dan Pendapatan Asli Daerah (Y)

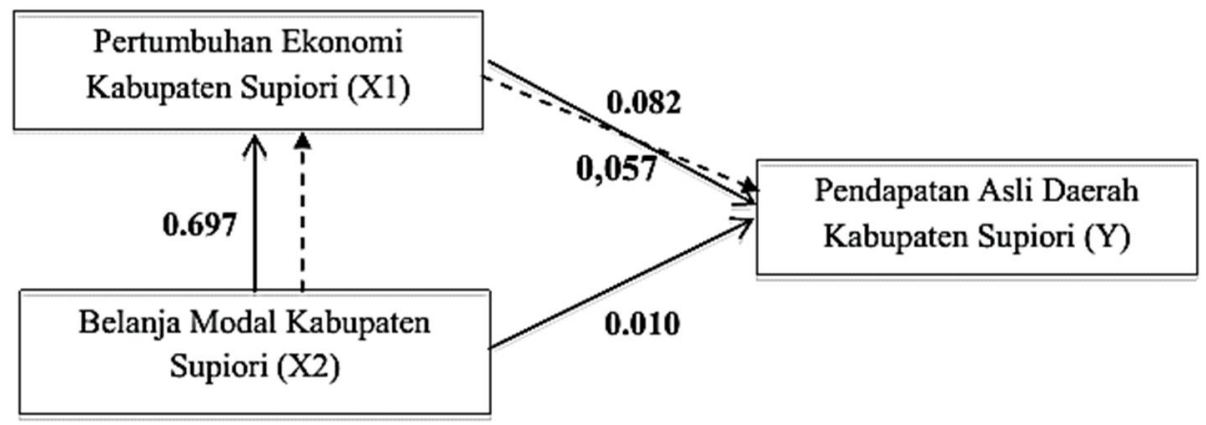

Untuk mengetahui pengaruh langsung, tidak langsung selanjutnya dilakukan transformasi koefisien jalur sebagaimana terlihat pada Gambar 4.8 di atas, kedalam tabel analisis dekomposisi dibawah ini:

Tabel 14

Analisis Dekomposisi Pengaruh Pertumbuhan Ekonomi (X1)

Terhadap Pertumbuhan Ekonomi (Y) Baik Secara Langsung Maupun Melalui Belanja Modal (X2) Sebagai Variabel Intervening

\begin{tabular}{|c|c|c|c|}
\hline \multirow{2}{*}{ Keterangan } & \multicolumn{3}{|c|}{ Pengaruh } \\
\cline { 2 - 4 } & Langsung & Melalui X1 & Total \\
\hline $\mathrm{X} 1>\mathrm{Y}$ & 0.082 & & 0.082 \\
\hline $\mathrm{X} 2>\mathrm{Y}$ & 0.010 & $(0.697)(0.082)=0.057$ & 0.067 \\
\hline
\end{tabular}

Sumber: data diolah, 2015

Dari tabel hasil analisis dekomposisi diatas dapat dimaknai bahwa koefisien jalur pengaruh langsung pertumbuhan ekonomi (X1) tehadap pendapatan asli daerah $(\mathrm{Y})$ adalah 0.082 , untuk pengaruh langsung belanja modal (X2) terhadap pendapatan asli daerah $(\mathrm{Y})$ 
hanya sebesar 0.010 , atau memliki pengaruh yang positif namun tidak signifikan, sehingga harus dikeluarkan dari model analisis jalur. Sedangkan pengaruh tidak langsung belanja modal (X2) melalui pertumbuhan ekonomi $(\mathrm{X} 1)$ terhadap pendapatan asli daerah $(\mathrm{Y})$ adalah 0.057 . Sehingga dapat disimpulkan bahwa pengaruh langsung lebih besar dari pengaruh tidak langsung (0.082>0.057). Maka dapat disimpulkan bahwa BM bukan merupakan variabel intervening.

Analisis jalur (Path Analysis) yang telah mengeluarkan hubungan variabel belanja modal terhadap pendapatan asli daerah, digambarkan melalui diagram jalur (path analysis) seperti terlihat pada gambar dibawah ini:

\section{Gambar 3}

Hasil Koreksi Analisis Jalur Hubungan Variabel Pertumbuhan Ekonomi (X1), Belanja Modal (X2) dan Pendapatan Asli Daerah (Y)

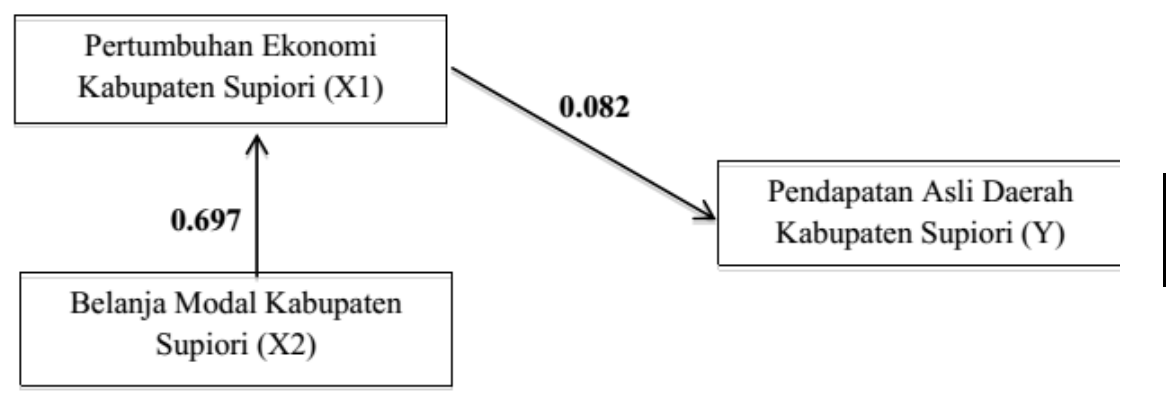

\section{Pengaruh Pertumbuhan Ekonomi Terhadap Pendapatan Asli Daerah (PAD)}

Hasil pengujian permasalahan pertama menunjukkan secara simultan variabel pertumbuhan ekonomi berpengaruh signifikan terhadap pendapatan asli daerah Kabupaten Supiori. Secara parsial variabel pertumbuhan ekonomi Kabupaten Supiori juga menunjukkan pengaruh yang cukup signifikan terhadap pendapatan asli daerah di wilayah tersebut $^{2}$. Berdasarkan temuan dari hasil penelitian tersebut bahwa; kondisi perekonomi Kabupaten Supiori berada dalam kondisi yang cukup baik. Pertumbuhan ekonomi tahun 2013 sebesar 4,73 persen. 
Angka ini mengalami perlambatan dibanding tahun 2012 yang sebesar 5,32 persen. Namun perekonomian Kabupaten Supiori selalu mengalami pertumbuhan yang positif. PDRB per kapita Kabupaten Supiori Tahun 2013 sebesar 27,968 juta rupiah. Nilai ini mengalami peningkatan dibanding tahun 2012 yang sebesar 26,366 juta rupiah.

\section{Pengaruh Belanja Modal Terhadap Pendapatan Asli Daerah (PAD) di Kabupaten Supiori}

Hasil pengujian permasalahan kedua menunjukkan secara simultan variabel belanja modal berpengaruh tidak signifikan terhadap pendapatan asli daerah Kabupaten Supiori. Secara parsial variabel Belanja Modal di Kabupaten Supiori berpengaruh positif terhadap pendapatan asli daerah di wilayah Kabupaten Supiori. Hal ini disebabkan oleh fokusnya pemerintah Kabupaten Supiori dalam melakukan pembangunan fisik gedung-gedung pemerintahan dan fasilitas jalan dan jembatan untuk membuka keterisoliran wilayah dan belum mengarahkan pembangunan infrastruktur yang mendorong peningkatan dunia usaha seperti pembangunan tempat wisata yang mampu menarik minat wisatawan mancanegara, dan infrastruktur lainnya yang berdampak langsung terhadap peningkatan pendapatan asli daerah.

\section{Pengaruh Belanja Modal Terhadap Pertumbuhan Ekonomi di Kabupaten Supiori}

Hasil pengujian permasalahan ketiga menunjukkan secara simultan variabel belanja modal berpengaruh signifikan terhadap pertumbuhan ekonomi di Kabupaten Supiori. Secara parsial variabel belanja modal yang dialokasikan oleh Pemerintah Kabupaten Supiori juga berpengaruh positif namun tidak signifikan terhadap penerimaan pendapatan asli daerah di Kabuaten Supiori. Hal ini terjadi karena belanja modal yang digunakan dalam pembangunan di Kabupaten Supiori masih terfokus pada pembangunan infrastruktur fisik, dan 
belum mengarah kepada peningkatan gairah usaha pada sektor-sektor perekonomian yang menunjang pertumbuhan ekonomi. Dimana sektor-sektor unggulan di Kabupaten Supiori seperti kelautan dan perikanan belum mendapatkan perhatian yang serius dari pemerintah daerah.

\section{Pengaruh Belanja Modal Terhadap Pendapatan Asli Daerah melalui Pertumbuhan Ekonomi di Kabupaten Supiori}

Pengujian untuk permasalahan keempat, ditemukan bahwa; secara simultan variabel pertumbuhan ekonomi dan belanja modal berpengaruh signifikan terhadap peningkatan pendapatan asli daerah di Kabupaten Supiori. Secara parsial variabel pertumbuhan ekonomi Kabupaten Supiori berpengaruh signifikan terhadap penerimaan pendapatan asli daerah di wilayah tersebut. Sedangkan untuk variabel belanja modal yang dialokasikan oleh Pemerintah Kabupaten Supiori tidak berpengaruh signifikan terhadap penerimaan pendapatan asli daerah di wilayah Kabupaten Supiori. Hasil penelitian penelitian tersebut menunjukkan bahwa pertumbukan ekonomi berpengaruh signifikan terhadap PAD sementara Belanja Modal memiliki pengaruh yang positif terhadap PAD namun tidak signifikan. Jika dilihat pola hubungan antara variabel yang ada, maka dapat disimpulkan bahwa belanja modal bukan merupakan variabel intervening bagi peningkatan pendapatan asli daerah di Kabupaten Supiori.

\section{KESIMPULAN DAN SARAN}

\section{Kesimpulan}

Dari hasil analisis dan pembahasan yang ada maka dapat ditarik beberapa kesimpulan yang menggambarkan hasil penelitian ini, antara lain bahwa;

a. Pertumbuhan ekonomi Kabupaten Supiori selama kurun waktu tahun 2008-2014, berpengaruh positif dan signifikan terhadap 
pendapatan asli daerah Kabupaten Supiori, baik itu secara parsial maupun secara simultan. Hal ini menunjukkan bahwa pertumbuhan ekonomi yang baik dan kondusifakan mendorong peningkatan pendapatan asli daerah di Kabupaten Supiori.

b. Pengalokasian belanja modal selama kurun waktu tahun 20082014, berpengaruh postif namun tidak signifikan terhadap pendapatan aslidaerah Kabupaten Supiori, baik itu secara parsial maupun secara simultan. Hal ini menunjukkan bahwa pengalokasian belanja modal yang terarah dan terencana dengan baik akan mendorong peningkatan pendapatan asli daerah di Kabupaten Supiori.

c. Sedangkan pengalokasian belanja modal dan pertumbuhan ekonomi selama kurun waktu tahun 2008-2014, memiliki pengaruh yang positif namun tidak signifikan terhadap penerimaan pendapatan aslidaerah Kabupaten Supiori, baik itu secara parsial maupun secara simultan. Hal ini menunjukkan bahwa pengalokasian belanja modal yang terarah dan terencana dengan baik dan peningkatan pertumbuhan ekonomi yang baik dan kondusif akan mendorong peningkatan pendapatan asli daerah di Kabupaten Supiori.

\section{Saran}

Berdasarkan kesimpulan hasil penelitian di atas, maka saran yang dapat diberikan melalui penelitian ini adalah:

a. Pemerintah Daerah Kabupaten Supiori diharapkan dapat menambah dan memperbaiki infrastruktur yang ada melalui peningkatan alokasi belanja modal, sehingga diharapkan dapat memacu pertumbuhan perekonomian di daerah dan pendapatan asli daerah 
b. Pemerintah Daerah Kabupaten Supiori juga harus mampu menciptakan peluang-peluang investasi yang mampu meningkatkan pertumbuhan ekonomi wilayah, sehingga diharapkan dapat memacu pendapatan asli daerah Kabupaten Supiori.

c. Pemerintah Daerah Kabupaten Supiori harus melakukan Pemetaan Wilayah sesuai dengan Potensi Sumber Daya Alam yang berpotensi terhadap PAD, serta meningkatkan kapasitas intelektual dari SDM yang ada serta menempatkannya sesuai kemampuan dan skiil yang dimilikinya untuk mengelola SDA yang tersedia di Kabupaten Supiori.

\section{DAFTAR PUSTAKA}

Adi, Priyo Hari. 2005. Dampak Desentralisasi Fiskal terhadap Pertumbuhan Ekonomi (Studi pada Kabupaten dan Kota Se Jawa Bali). Simposium Nasional Akuntasi IX, Padang 23-26 Agustus 2006

Andirfa, Mulia. 2009. Pengaruh Pertumbuhan Ekonomi, Pendapatan Asli Daerah, Dana Perimbangan, dan Lain-lain Pendapatan yang Sah Terhadap Pengalokasian Anggaran Belanja Modal. Skripsi. Fakultas Ekonomi Jurusan Akuntansi Universitas Syiah Kuala Darussalam, Banda Aceh.

Badan Perencanaan dan Pembangunan Kabupaten Supiori, 2009, 2010, 2011, 2012, 2013 dan 2014, Supiori Dalam Angka;

David Harianto, dan Priyo Hari Adi. 2007. Hubungan Antara Dana Alokasi Umum, Belanja Modal, Pendapatan Asli Daerah dan Pendapatan Per Kapita. Simposium Nasional Akuntansi X, Makasar, 26-28 Juli 2007.

Ghozali, Imam. 2006. Aplikasi Analisis Multivariate dengan Program SPSS. Cetakan IV. Badan Penerbit Universitas Diponegoro. Semarang.

Kabupaten Supiori 2008, 2009, 2010, 2011, 2012, 2013 dan 2014 Laporan Keuangan Pemerintah Daerah Kabupaten Supiori;

Naz'aina. 2013. Analisis Hubungan Antara Pertumbuhan Ekonomi Daerah, Belanja Pembangunan Daerah dan Pendapatan Asli 
Daerah Kabupaten Aceh Utara, Pekbis Jurnal, Vol.5, No.1, Maret 2013:24-32.

Undang-Undang Nomor 17 Tahun 2003 tentang Keuangan Negara

Santoso. 2005. Statistik Parametrik. Penerbit Elex Media Computindo. Jakarta.

Vani Christalia Putri. 2011. Studi Belanja Modal, Pertumbuhan Ekonomi dan Pendapatan Asli Daerah di Sumatera Barat. Skripsi.

Wandira, Arbie 2013, Pengaruh PAD, DAU, DAK, dan DBH Terhadap Belanja Modal, Jurnal Akuntansi (Diakses Tanggal 17 September 2014) 